\title{
Effect of liquid retentate storage on flavor of spray-dried whey protein concentrate and isolate
}

\author{
M. Whitson, ${ }^{*}$ R. E. Miracle, ${ }^{*}$ E. Bastian, $\dagger$ and M. A. Drake ${ }^{* 1}$ \\ ${ }^{*}$ Department of Food, Bioprocessing and Nutrition Sciences, Southeast Dairy Foods Research Center, North Carolina State University, \\ Raleigh 27695 \\ †Glanbia Nutritionals, 450 Falls Ave. Suite 255, Twin Falls, ID 83301
}

\section{ABSTRACT}

The objective of this study was to determine the effects of holding time of liquid retentate on flavor of spray-dried whey proteins: Cheddar whey protein isolate (WPI) and Mozzarella 80\% whey protein concentrate (WPC80). Liquid WPC80 and WPI retentate were manufactured and stored at $3^{\circ} \mathrm{C}$. After $0,6,12,24$, and $48 \mathrm{~h}$, the product was spray-dried $(2 \mathrm{~kg})$ and the remaining retentate held until the next time point. The design was replicated twice for each product. Powders were stored at $21^{\circ} \mathrm{C}$ and evaluated every 4 mo throughout 12 mo of storage. Flavor profiles of rehydrated proteins were documented by descriptive sensory analysis. Volatile components were analyzed with solid phase microextraction coupled with gas chromatography mass spectrometry. Cardboard flavors increased in both spray-dried products with increased retentate storage time and cabbage flavors increased in WPI. Concurrent with sensory results, lipid oxidation products (hexanal, heptanal, octanal) and sulfur degradation products (dimethyl disulfide, dimethyl trisulfide) increased in spray-dried products with increased liquid retentate storage time, whereas diacetyl decreased. Shelf stability was decreased in spray-dried products from longer retentate storage times. For maximum quality and shelf life, liquid retentate should be held for less than $12 \mathrm{~h}$ before spray drying.

Key words: whey protein, retentate, storage, flavor

\section{INTRODUCTION}

Whey protein is one of the major players in the growing functional foods market, valued to be $>\$ 100$ billion by 2012 (Smithers, 2008). Whey protein is mainly used in 2 forms: whey protein concentrate (34-89\% protein; WPC) and whey protein isolate (>90\% protein; WPI). In 2007, 357.4 million pounds of WPC was produced worldwide (IDFA, 2008). Although production and applications are increasing, Smithers (2008)

Received November 27, 2010.

Accepted March 18, 2011.

${ }^{1}$ Corresponding author: mdrake@unity.ncsu.edu blamed inconsistency and unreliability of whey proteins in food systems as the main reason for restricted whey protein utilization over the past 25 yr. Both nutritional and functional characteristics of whey protein are used in food applications. Whey proteins exhibit low sensory flavor intensities, but off-flavors may frequently carry through into ingredient applications, limiting product success (Drake, 2006; Childs et al., 2007; Drake et al., 2009a,b; Wright et al., 2009; Evans et al., 2010).

Off-flavors in dried whey ingredients may result from many different factors and chemical reactions. Such factors and reactions may include riboflavin effects, Maillard browning, and lipid oxidation (Sattar and deMan, 1975; Rinn et al., 1990; Morr and Ha, 1991; Carunchia Whetstine et al., 2003; Tomaino et al., 2004; GallardoEscamilla et al., 2005). Volatile lipid oxidation products (VLOP) have been associated with cardboard flavor in dairy products, which is a common off-flavor in dried whey products (Drake et al., 2009a; Wright et al., 2009; Whitson et al., 2010). Tomaino et al. (2004) hypothesized that transportation and storage of liquid whey could dramatically affect the flavor of the finished whey powder after concentration and drying. Tomaino et al. (2004) documented an increase of VLOP over a 14-d liquid whey storage period. Tomaino et al. (2004) did not remove the fat from the pilot plant-produced fluid whey in their study nor did they process the liquid whey to a final, spray-dried product. Fat removal is a standard industrial process step and as such, the results from Tomaino et al. (2004) would represent the worstcase scenario in regards to lipid oxidation. More recently, Liaw et al. (2010) compared flavor of fluid Cheddar and Mozzarella wheys. They documented increases in cardboard flavors and lipid oxidation products in fluid wheys across $3 \mathrm{~d}$ of storage at $3^{\circ} \mathrm{C}$. Undesirable flavors increased in dried whey protein during storage and were due at least in part to increases in volatile lipid oxidation products (Javidipour and Qian, 2008; Wright et al., 2009).

During whey production, many processing steps occur that may influence whey protein flavor. Croissant et al. (2009) demonstrated that bleaching of fluid whey and the choice of bleaching agent used negatively 
influenced flavor via production of lipid oxidation compounds, whereas Liaw et al. (2010) demonstrated that fluid whey storage and fat content of the fluid whey had a direct influence on lipid oxidation. Storage of fluid retentate is another source of off-flavors. Concentrated liquid whey (retentate) may be stored in temperaturecontrolled tanks for up to $48 \mathrm{~h}$ before spray drying. Storage and storage time are variable within and between facilities. During this storage time, chemical reactions may occur that produce off-flavors in spraydried whey protein. If off-flavor production increases during storage of liquid whey protein retentate, then whey processors would be encouraged to spray dry immediately after concentration or methods to minimize oxidation during liquid storage should be identified. The objective of this research was to determine the effects of storage time of liquid whey protein retentate on flavor and flavor stability of spray-dried whey proteins: Cheddar WPI and Mozzarella WPC80.

\section{MATERIALS AND METHODS}

\section{Experimental Design}

Two industrial manufacturers (a Cheddar WPI manufacturer on the west coast of the United States and a Mozzarella WPC80 manufacturer in the Midwest) of whey protein were contacted and agreed to participate in the study. These manufacturers were selected based on their interest and willingness to participate, representation of Mozzarella and Cheddar whey products, as well as their pilot-plant storage and drier facilities, which were required to enable them to participate in the study. Each facility, on 2 separate occasions, collected 2,271 L of liquid whey protein retentate (Mozzarella WPC80 retentate: $28.27 \pm 0.62 \%$ solids, $23.18 \pm 0.68 \%$ protein; Cheddar WPI retentate: $28.39 \pm 0.36 \%$ solids, $25.87 \pm 0.43 \%$ protein). For each facility, pasteurization or heat treatment of liquid whey was a standard processing step before ultrafiltration to control starter growth. Mozzarella WPC80 retentate was manufactured by ultrafiltration and diafiltration of fluid whey to $80 \%$ protein using polyethersulfone spiral-wound UF membranes. Cheddar WPI retentate was manufactured by ultrafiltration and diafiltration of fluid whey to $34 \%$ protein using polyethersulfone spiral-wound UF membranes followed by microfiltration with ceramic membranes to $90 \%$ protein. The liquid retentate was subsequently immediately spray-dried at the manufacturer's pilot plant facility (Mozzarella WPC80 or Cheddar WPI) or held at $3^{\circ} \mathrm{C}$ in a stainless steel temperature-controlled holding tank for $6,12,24$, or $48 \mathrm{~h}$ before spray drying. At each time point, a portion of the liquid retentate was collected and frozen, and another portion was spray-dried and the powder collected. Approximately $2.4 \mathrm{~L}$ of frozen liquid whey retentate and $2 \mathrm{~kg}$ of powdered whey protein were received for each time point. Liquid samples were shipped on dry ice and spray-dried samples were shipped on ice gel packs by overnight carrier to North Carolina State University (Raleigh). Upon receipt, retentate and dried products were stored at $-80^{\circ} \mathrm{C}$ until analysis.

\section{Whey Protein Production: Mozzarella WPC80 and Cheddar WPI Process Overview}

Mozzarella WPC80 retentate was collected from the commercial ultrafiltration/diafiltration filtration system and immediately transported via truck to the industrial pilot plant facility in a 189-L high-density polyethylene drum. Temperature of the retentate was approximately $3^{\circ} \mathrm{C}$. It took approximately $2 \mathrm{~h}$ to transport the drum from the manufacturing plant to the pilot plant. Retentate temperature did not change during transport. Upon arrival, a liquid sample was taken for shipment to North Carolina State University and approximately $38 \mathrm{~L}$ was immediately spray-dried. The remaining retentate was placed in a jacketed stainless steel tank. Chilled water was circulated through the jacket of the tank to maintain a retentate temperature of $3^{\circ} \mathrm{C}$. The agitator of the tank was turned off, except for a few minutes before each sampling. The liquid samples were collected in 4-L low-density, polyethyleneblend amber cube containers (Hedwin, VWR International, West Chester, PA) and immediately frozen at $-40^{\circ} \mathrm{C}$. Sampling occurred at the prescribed intervals. The retentate was spray-dried at each time point on a pilot-scale drier. Inlet drier temperature was $182^{\circ} \mathrm{C}$ and the outlet temperature was $91^{\circ} \mathrm{C}$. Pressure atomization was used on a single nozzle. Dry powder samples were collected and immediately sealed in polyester film (Mylar) bags (Impak Corp., Los Angeles, CA). The drier was not cleaned between intervals, but all liquid delivery equipment, such as the drier tanks, pumps, and piping, was cleaned after each sample was dried. This process was replicated on 2 occasions. The process for Cheddar WPI production was similar except that pilot-plant facilities were adjacent to the manufacturing facility and no transportation or time delay occurred between collection of retentate and spray-drying of the first time point.

\section{Sample Preparation}

Frozen liquid WPC80 and WPI retentate were quickly thawed by placing the containers in a room temperature water bath. The water was continually replenished to accelerate thawing. Overall thawing time 
was $1 \mathrm{~h} 45 \mathrm{~min}$. Samples from all time points $(0,6$, 12,24 , and $48 \mathrm{~h}$ ) were thawed at the same time. After thawing, the liquid samples were then diluted to $10 \%$ solids by adding $300 \mathrm{~mL}$ of deodorized water to $150 \mathrm{~mL}$ of retentate. This diluted whey was then portioned into random 3-digit-coded, lidded sample cups for descriptive sensory analysis. Another set of sample vials were filled with a small portion of thawed whey to be used for volatile analysis. Spray-dried samples (300 g) were stored in Mylar bags (Impak Corp.) at $-80^{\circ} \mathrm{C}$ until sensory and instrumental analysis (less than $120 \mathrm{~d}$ ). Additional spray-dried WPC80 and WPI (300 g) were stored in Mylar bags at room temperature $\left(20 \pm 1^{\circ} \mathrm{C}\right.$, $50 \%$ relative humidity) for up to $1 \mathrm{yr}$. During that time, products were analyzed every 4 mo by sensory and volatile compound analysis to document storage time effects.

\section{Proximate Analysis}

Proximate analyses were conducted in duplicate on each sample. Analysis of total solids in retentate or moisture in WPC and WPI was conducted by forced draft oven. Total nitrogen was determined by Kjeldahl analysis and converted to protein using a conversion factor of 6.38 (Wehr and Frank, 2004). Fat content of WPC and WPI was determined by the Mojonnier method (Mojonnier Bros. Co., Chicago, IL; Wehr and Frank, 2004). Color measurements were taken with a hand-held Minolta Chromameter CR-300 (Minolta Camera Co., Tokyo, Japan) for all powder WPC80 and WPI hold times at each 4 mo analysis time point during powder storage. The WPC80 or WPI powder was placed into $60 \times 15 \mathrm{~mm}$ round polystyrene Petri dishes (Becton Dickinson Labware, Franklin Lakes, NJ), and $\mathrm{L}^{*} \mathrm{a} \mathrm{b}^{*}$ (lightness, redness, yellowness, respectively) measurements were taken at 4 random places on each Petri dish.

\section{Descriptive Analysis}

Descriptive sensory analysis was performed on liquid retentate (adjusted to 10\% solids) and rehydrated spray-dried WPC and WPI. Panelists $(\mathrm{n}=10)$ each had more than $100 \mathrm{~h}$ of previous experience with the sensory analysis of dairy products using the Spectrum descriptive analysis method (Meilgaard et al., 1999) and an established sensory language for liquid and dried whey products (Drake et al., 2009a; Wright et al., 2009). Liquid and spray-dried samples were evaluated at $10 \%$ solids (wt/vol). A warm-up sample and deionized water were provided. Aroma was first evaluated by cracking the lid of the sample cup and using short sniffs followed by flavor analysis in the mouth.
Attribute intensities were scored using a 15-point (0 to 15) universal intensity scale consistent with the Spectrum method (Meilgaard et al., 1999). Both liquid and powder samples were evaluated at room temperature and each sample was evaluated in duplicate by each panelist. Data were collected using paper ballots or Compusense Five, version 4.8 (Compusense, Guelph, ON, Canada).

\section{Headspace Extraction of Volatile Compounds}

Solid-phase microextraction (SPME) followed by GC-MS was conducted using a modified method from Wright et al. (2006), on both liquid and powders at time 0 and following 4, 8, and 12 mo of storage for WPC80 and WPI powders. For GC-MS analysis preparation, WPC80 and WPI liquid retentate for each time point was diluted to $10 \%$ solids using HPLC-grade water (EMD Chemicals Inc., Gibbstown, NJ). Five milliliters of diluted liquid whey retentate and $0.5 \mathrm{~g}$ of sodium chloride (Sigma Aldrich, Milwaukee, WI) were added to 20-mL autosampler vials with steel screw tops containing silicone septa faced in Teflon (Microliter Analytical, Suwanee, GA). Powdered WPC80 and WPI were rehydrated to $10 \%$ solids in HPLC-grade water. Sodium chloride was also added at $10 \%$ (wt/vol). Five milliliters of whey/salt solution was added to $20-\mathrm{mL}$ autosampler vials with steel screw tops containing silicone septa faced in Teflon (Microliter Analytical), and each vial was spiked with $10 \mu \mathrm{L}$ of internal standard solution (2-methyl-3-heptanone in methanol at 8.1 $\mathrm{mg} / \mathrm{kg}$ ). A CombiPal autosampler (CTC Analytics, Zwingen, Switzerland) was used for injection into an attached Agilent 6890N GC with a 5973 inert MSD (Agilent Technologies Inc., Santa Clara, CA). Vials were placed in a randomized balanced order in the autosampler to account for the time delay during sample analysis (analysis time for 1 sample was $47 \mathrm{~min}$ ). Vial temperature was maintained at $5^{\circ} \mathrm{C}$ before fiber exposure. Samples were equilibrated at $40^{\circ} \mathrm{C}$ for $25 \mathrm{~min}$ before $30 \mathrm{~min}$ of fiber exposure of a 1-cm divinylbenzene/ carboxen/polydimethylsiloxane (DVB/CAR/PDMS) fiber (Supelco, Bellefonte, PA) at $31 \mathrm{~mm}$ with $4 \mathrm{~s}$ of pulsed agitation at $250 \mathrm{rpm}$. Fibers were injected for 5 min at a depth of $50 \mathrm{~mm}$. The GC method used an initial temperature of $40^{\circ} \mathrm{C}$ for 3 min with a ramp rate of $10^{\circ} \mathrm{C} / \mathrm{min}$ to $250^{\circ} \mathrm{C}$ held for $5 \mathrm{~min}$. The SPME fibers were introduced into the split/splitless injector at $250^{\circ} \mathrm{C}$. An Rtx- $5 \mathrm{~ms}$ column (Rtx- $5 \mathrm{~ms} 30 \mathrm{~m}$ length $\times 0.25 \mathrm{~mm}$ inner diameter $\times 0.25-\mu \mathrm{m}$ film thickness; Restek, Bellefonte, PA) was used for all analyses at a constant flow rate of $1 \mathrm{~mL} / \mathrm{min}$. Purge time was set at $1 \mathrm{~min}$. The MS transfer line was maintained at $250^{\circ} \mathrm{C}$ with the Quad at $150^{\circ} \mathrm{C}$ and Source at $250^{\circ} \mathrm{C}$. The 
Table 1. Descriptive sensory analysis of liquid Mozzarella retentate across various retentate hold times

\begin{tabular}{lccccc}
\hline & \multicolumn{5}{c}{ Retentate hold time (h) } \\
\cline { 2 - 6 } Attribute $^{1}$ & 0 & 6 & 12 & 24 & 48 \\
\hline Aroma intensity & $1.18^{\mathrm{b}}$ & $1.28^{\mathrm{b}}$ & $1.33^{\mathrm{b}}$ & $1.42^{\mathrm{b}}$ & $1.75^{\mathrm{a}}$ \\
Cooked milky & $1.33^{\mathrm{a}}$ & $1.00^{\mathrm{a}-\mathrm{b}}$ & $1.05^{\mathrm{ab}}$ & $0.67^{\mathrm{c}}$ & $0.75^{\mathrm{bc}}$ \\
Cardboard & $\mathrm{ND}^{2}$ & $\mathrm{ND}$ & $\mathrm{ND}$ & $1.12^{\mathrm{a}}$ & $1.38^{\mathrm{a}}$ \\
Cereal & $1.25^{\mathrm{a}}$ & $1.13^{\mathrm{a}}$ & $1.22^{\mathrm{a}}$ & $1.12^{\mathrm{a}}$ & $1.00^{\mathrm{a}}$ \\
Astringency & $1.75^{\mathrm{b}}$ & $2.22^{\mathrm{ab}}$ & $2.08^{\mathrm{b}}$ & $2.10^{\mathrm{b}}$ & $2.68^{\mathrm{a}}$ \\
Serumy & $0.88^{\mathrm{c}}$ & $1.57^{\mathrm{ab}}$ & $1.45^{\mathrm{b}}$ & $1.43^{\mathrm{b}}$ & $1.95^{\mathrm{a}}$ \\
\hline
\end{tabular}

${ }^{\mathrm{a}-\mathrm{c}}$ Means in row followed by different letters are different $(P<0.05)$.

${ }^{1}$ Intensities are scored on a 0 - to 15 -point universal scale, where $0=$ none and $15=$ very high (Meilgaard et al., 1999). Most dried ingredient flavor intensities fall between 0 and 4 on this scale (Drake et al., 2003, 2009a,b; Wright et al., 2009).

${ }^{2} \mathrm{ND}=$ not detected consistently by all panelists; mean intensity score $<0.50$.

WPC80 and WPI liquid and powder retentate from each time point were analyzed in triplicate.

\section{Compound Identification}

For positive identification of volatile compounds, ion spectra of compounds were compared with the NIST 2005 library of spectra and spectra of authentic standards injected under identical conditions. Recovery of the internal standard concentration was used to calculate the relative abundance of each compound identified. Retention indices were calculated using an alkane series (Sigma Aldrich, Milwaukee, WI; van den Dool and Kratz, 1963).

\section{Statistical Analysis}

Statistical differences in sensory and instrumental data were determined by ANOVA using Fisher's Least Significant Difference as a post hoc test (XLStat, version 2009, Addinsoft, Paris, France). Principal component analysis was used to visualize the effect of hold times $(0,6,12,24$, and $48 \mathrm{~h})$ on the sensory attributes and volatile compound profiles of spray-dried products.

\section{RESULTS AND DISCUSSION}

\section{Composition of WPC80 and WPI}

No compositional differences were observed between the 0 and $48 \mathrm{~h}$ time points for Mozzarella liquid retentate $(P>0.05)$. Ash was $0.82 \pm 0.05 \%$, total solids was $28.2 \pm 0.62 \%$, protein was $23.2 \pm 0.68 \%$, and fat was $1.35 \pm 0.02 \%$, respectively. Proximate analysis of Mozzarella WPC80 from each storage point were also similar (carbohydrate $10.09 \pm 0.49 \%$; ash $2.75 \pm 0.09 \%$; moisture $6.28 \pm 1.21 \%$; protein $76.44 \pm 1.06 \%$; fat 4.45 $\pm 0.11 \%$, and $\mathrm{pH} 6.11 \pm 0.04 ; P>0.05)$.
Proximate analysis of Cheddar WPI retentate was also consistent $(P>0.05)$. Ash content was $3.08 \pm$ $0.05 \%$; total solids was $28.39 \pm 0.24 \%$; protein was 25.9 $+0.3 \%$, and fat was $0.06 \pm 0.01 \%$. Proximate analysis of Cheddar WPI from each storage point was also similar (ash $3.04 \pm 0.03 \%$, moisture $4.68 \pm 1.12 \%$; protein $88.65 \pm 1.02 \%$; fat $0.40 \pm 0.03 \%, \mathrm{pH} 6.29 \pm 0.07 ; P>$ 0.05). All products (Mozzarella and Cheddar; powder and liquid retentate) were within expected ranges for their proximate compositions (Jelen, 2000).

\section{Sensory Descriptive Analysis}

Aroma and flavor attributes detected in all samples could be split into 2 groups: dairy flavors, which are flavors associated with fresh fluid milk or whey (cooked/ milky, diacetyl, cereal), and nondairy flavors, which are flavors not associated with fresh fluid milk or whey (cardboard, cabbage, serumy, fatty) (Drake et al., 2003, 2009a,b, 2010; Carunchia Whetstine et al., 2005). For ingredient applications, whey proteins should have as little flavor as possible. Milder fresh dairy flavors in whey proteins are easier to incorporate into other food systems (ingredient applications) compared with nondairy flavors in whey proteins. Cardboard, cabbage, and fatty flavors in whey proteins readily carry through into beverage applications (Caudle et al., 2005; Drake et al., 2009b; Wright et al., 2009).

Liquid Mozzarella Retentate. Aroma intensity increased with retentate hold time. Aroma intensity was highest for the $48 \mathrm{~h}$ time point, whereas samples at $0,6,12$, and $24 \mathrm{~h}$ had lower aroma intensities (Table 1, Figure 1). Cardboard and serumy flavors and astringency also increased with increased retentate hold time. In contrast, cooked/milky flavor decreased as retentate hold time increased. These observations in fluid retentate are consistent with previous studies on fluid whey, which demonstrated that flavors associated 
Biplot (axes PC1 and PC2: 94\%)

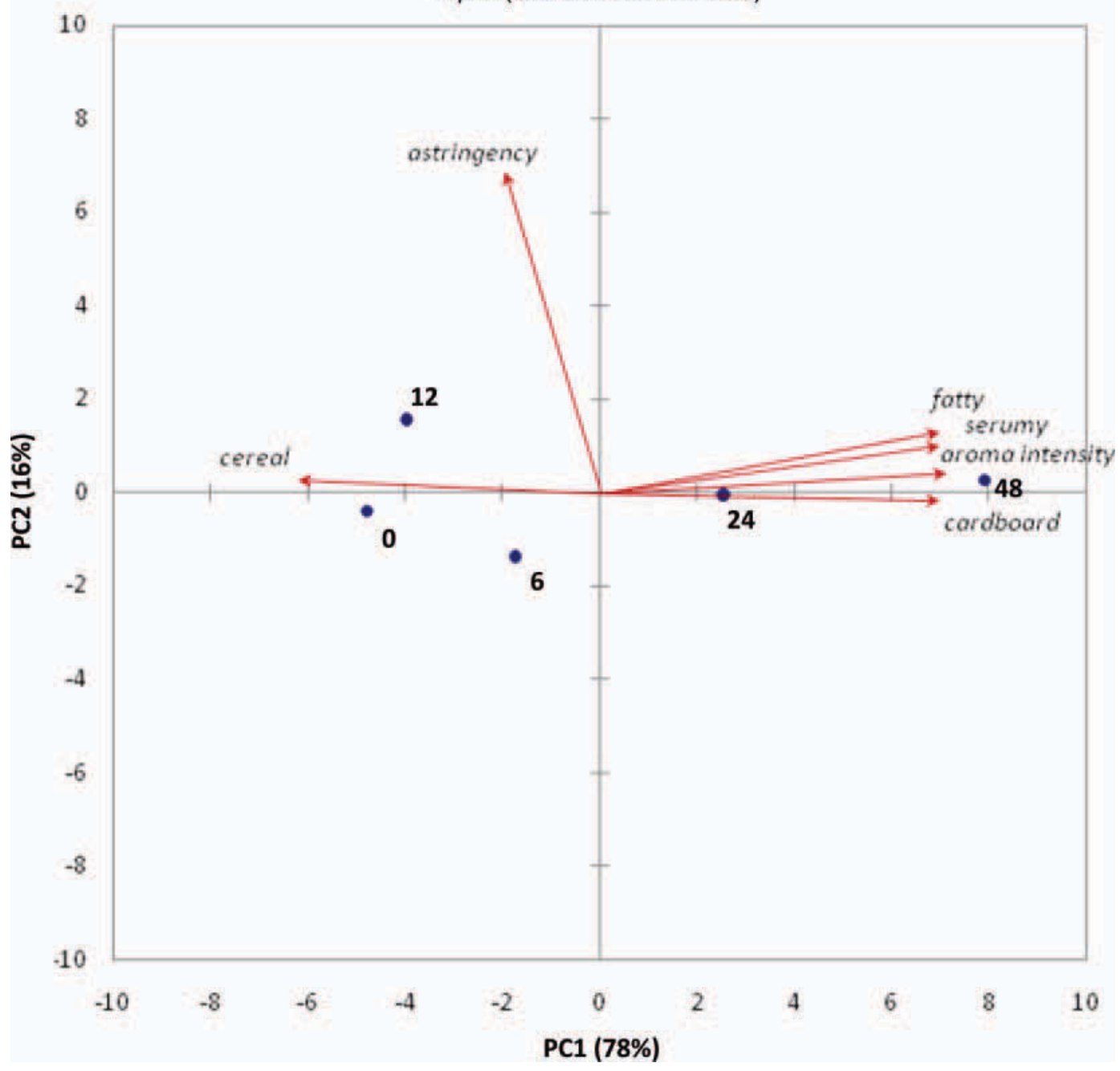

Figure 1. Descriptive sensory analysis principal component (PC) biplot of Mozzarella whey protein concentrate (WPC80) from liquid retentate stored for $0,6,12,24$, or $48 \mathrm{~h}$. Color version available in the online PDF.

with fresh fluid milk or whey (cooked/milky, diacetyl, cereal) decreased with refrigerated storage, whereas sensory intensities of nondairy flavors (cardboard, cabbage, serumy, fatty) increased (Carunchia Whetstine et al., 2003; Liaw et al., 2010).

Mozzarella WPC80. Similar to the liquid retentate results, Mozzarella WPC80 also increased in aroma intensity, cardboard, and serumy flavors as the retentate hold time increased from 0 to $48 \mathrm{~h}(P<0.05$; Table 2, Figure 2). Fatty flavor also increased with retentate hold time $(P<0.05)$. No statistical difference was detected for astringency. Flavor attributes were more intense for Mozzarella WPC80 than for liquid Mozzarella retentate, even initially, which might suggest that spray-drying pronounces flavor perception and differences.
Liquid Cheddar Retentate. Flavor differences were found between Cheddar and Mozzarella retentates (Tables 1 and 3). Mozzarella retentate had cooked/ milky and serumy flavors that were not documented in Cheddar retentates. Previous work has demonstrated that fluid Mozzarella and Cheddar whey are distinct in flavor (Liaw et al., 2010) as are WPC80 from Cheddar or Mozzarella whey (Wright et al., 2009) so it is not surprising that retentates were also distinct. Liaw et al. (2010) hypothesized that starter culture differences were the source of the distinct volatile compound profiles in these products. However, WPI retentate was also distinct in composition from Mozzarella retentate even when rehydrated to the same percentage solids; namely, WPI retentates had higher protein and less fat than Mozzarella retentates. These compositional differ- 
Table 2. Descriptive sensory analysis of Mozzarella whey protein concentrate (WPC80) 0 mo across varying retentate hold times

\begin{tabular}{lccccc}
\hline & \multicolumn{5}{c}{ Retentate hold time $(\mathrm{h})$} \\
\cline { 2 - 6 } Attribute $^{1}$ & 0 & 6 & 12 & 24 & 48 \\
\hline Aroma intensity & $1.33^{\mathrm{b}}$ & $1.58^{\mathrm{b}}$ & $1.45^{\mathrm{b}}$ & $1.90^{\mathrm{ab}}$ & $2.45^{\mathrm{a}}$ \\
Cardboard & $1.00^{\mathrm{b}}$ & $1.23^{\mathrm{b}}$ & $1.05^{\mathrm{b}}$ & $1.75^{\mathrm{a}}$ & $1.95^{\mathrm{a}}$ \\
Cereal & $1.50^{\mathrm{a}}$ & $1.30^{\mathrm{ab}}$ & $1.38^{\mathrm{ab}}$ & $1.33^{\mathrm{ab}}$ & $1.15^{\mathrm{b}}$ \\
Astringency & $2.05^{\mathrm{a}}$ & $2.00^{\mathrm{a}}$ & $2.15^{\mathrm{a}}$ & $2.05^{\mathrm{a}}$ & $2.05^{\mathrm{a}}$ \\
Serumy & $\mathrm{ND}^{2}$ & $\mathrm{ND}$ & $\mathrm{ND}$ & $0.75^{\mathrm{b}}$ & $1.13^{\mathrm{a}}$ \\
Fatty & $\mathrm{ND}$ & $\mathrm{ND}$ & $\mathrm{ND}$ & $0.83^{\mathrm{b}}$ & $1.78^{\mathrm{a}}$ \\
\hline
\end{tabular}

$\overline{\mathrm{a}, \mathrm{b}}$ Means in row followed by different letters are different $(P<0.05)$.

${ }^{1}$ Intensities are scored on a 0 - to 15 -point universal scale, where $0=$ none and $15=$ very high (Meilgaard et al., 1999). Most dried ingredient flavor intensities fall between 0 and 4 on this scale (Drake et al., 2003, 2009a,b; Wright et al., 2009).

${ }^{2} \mathrm{ND}=$ not detected consistently by all panelists; mean intensity score $<0.50$.

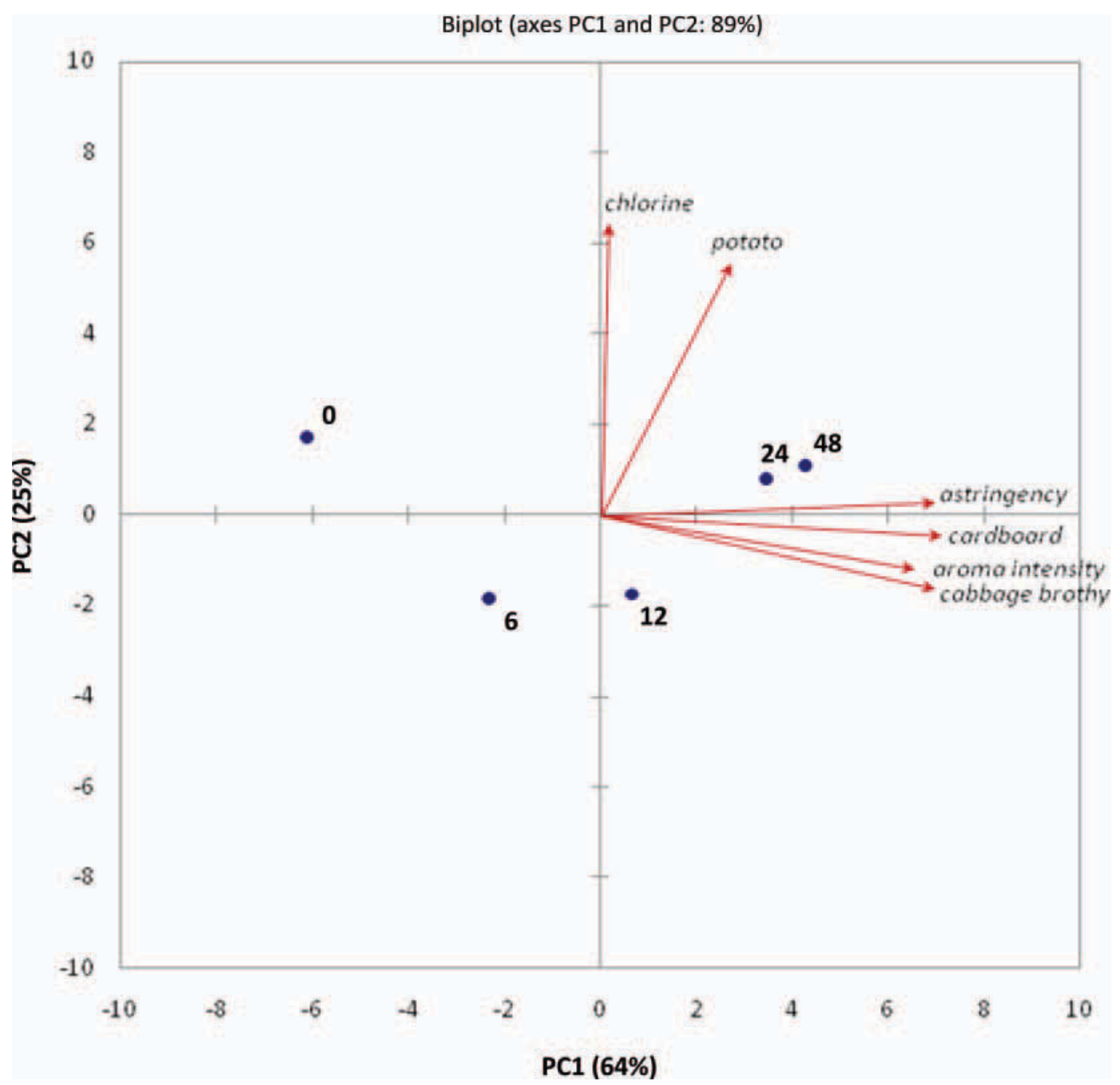

Figure 2. Descriptive sensory analysis principal component (PC) biplot of Cheddar whey protein isolate from liquid retentate stored for 0 , $6,12,24$, or $48 \mathrm{~h}$. Color version available in the online PDF. 
Table 3. Descriptive sensory analysis of liquid Cheddar retentate across varying retentate hold times

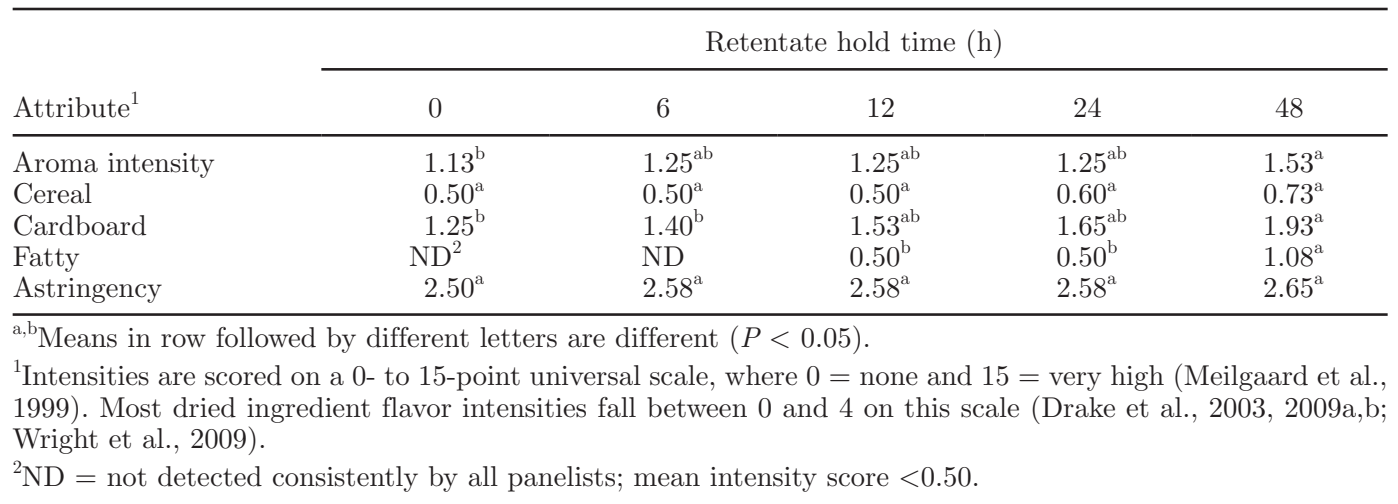

ences could also contribute to the observed differences in flavor. Both Cheddar and Mozzarella retentates had a fatty flavor that increased with storage time. Other flavor attributes were similar for both types of retentates. Aroma intensity, cardboard, and fatty attributes all increased in Cheddar retentate as hold time increased (Table 3). Once again, these observations are consistent with previous work with fluid Mozzarella and Cheddar whey (Liaw et al., 2010).

Cheddar WPI. Cabbage/brothy, potato, and chlorine flavors were descriptive sensory attributes that have been associated with Cheddar whey protein and not Mozzarella whey protein (Wright et al., 2009). Aroma intensity, cabbage/brothy, and cardboard flavor increased in Cheddar WPI between 0 and $48 \mathrm{~h}$ of retentate storage (Table 4). Cardboard flavor showed the greatest increase, starting at intensities of 0.9 for 0 $\mathrm{h}$ and increasing to 2.4 in WPI from retentate stored for $48 \mathrm{~h}$ at $3 \mathrm{C}$. No discernable trend was observed for chlorine flavor among the time points. No statistical differences were detected for potato flavor or astringency.

SPME GC-MS of Liquid WPC80 and WPI Retentates. Hexanal and heptanal concentrations increased with increased retentate storage time (Table 5). Other aldehydes (butanal, octanal, and decanal) were not different $(P>0.05$; Figure 3$)$. Overall aldehyde concentration increased by $48 \mathrm{~h}$ of retentate storage for Mozzarella WPC80 liquid retentate, and while aldehydes increased, diacetyl concentration decreased $(P<$ 0.05). Tomaino et al. (2004) and Carunchia Whetstine et al. (2003) documented increases in aldehydes with refrigerated storage of fluid whey. A decrease in diacetyl was also observed. Volatile results were consistent with sensory results: both indicated that as retentate storage time increased, fresh flavors decreased and off-flavors increased. Volatile lipid oxidation products were also detected by SPME GC-MS for Cheddar WPI liquid retentate (Table 6). Unlike those in Mozzarella retentate, relative concentrations of compounds examined in Cheddar WPI retentate were not different across $48 \mathrm{~h}$ of storage at $3{ }^{\circ} \mathrm{C}(P>0.05)$. Once again, composition differences may explain why changes were observed in Mozzarella WPC80 retentate but were not detected in Cheddar WPI retentate. The low fat content of WPI retentate should minimize lipid oxidation compared with WPC80 retentate. Beyond aldehydes, the sulfur compounds dimethyl disulfide and dimethyl trisulfide were also detected in the Cheddar WPI retentate, consistent with sensory detection of sulfur flavors (cabbage and potato flavors in the spray-dried Cheddar WPI).

Table 4. Descriptive sensory analysis of Cheddar whey protein isolate (0 mo) across varying retentate hold times

\begin{tabular}{lcllll}
\hline & \multicolumn{5}{c}{ Retentate hold time $(\mathrm{h})$} \\
\cline { 2 - 5 } Attribute $^{1}$ & 0 & 6 & 12 & 24 & 48 \\
\hline Aroma intensity & $1.55^{\mathrm{b}}$ & $1.90^{\mathrm{ab}}$ & $2.18^{\mathrm{ab}}$ & $2.53^{\mathrm{a}}$ & $2.20^{\mathrm{ab}}$ \\
Cabbage brothy & $\mathrm{ND}^{2}$ & $0.88^{\mathrm{b}}$ & $1.18^{\mathrm{b}}$ & $1.18^{\mathrm{b}}$ & $1.60^{\mathrm{a}}$ \\
Potato & $0.50^{\mathrm{a}}$ & $\mathrm{ND}$ & $\mathrm{ND}$ & $0.90^{\mathrm{a}}$ & $0.50^{\mathrm{a}}$ \\
Cardboard & $0.88^{\mathrm{c}}$ & $1.53^{\mathrm{bc}}$ & $1.83^{\mathrm{ab}}$ & $2.13^{\mathrm{ab}}$ & $2.38^{\mathrm{a}}$ \\
Chlorine & $0.63^{\mathrm{a}}$ & $\mathrm{ND}$ & $\mathrm{ND}$ & $\mathrm{ND}^{\mathrm{a}}$ & $0.70^{\mathrm{a}}$ \\
Astringency & $1.83^{\mathrm{a}}$ & $1.88^{\mathrm{a}}$ & $1.93^{\mathrm{a}}$ & $1.95^{\mathrm{a}}$ & $2.00^{\mathrm{a}}$ \\
\hline
\end{tabular}

${ }^{\mathrm{a}-\mathrm{c}}$ Means in row followed by different letters are different $(P<0.05)$.

${ }^{1}$ Intensities are scored on a 15 -point universal scale, where $0=$ none and $15=$ very high (Meilgaard et al., 1999). Most dried ingredient flavor intensities fall between 0 and 4 on this scale (Drake et al., 2003, 2009a,b; Wright et al., 2009).

${ }^{2} \mathrm{ND}=$ not detected consistently by all panelists; mean intensity score $<0.50$. 
Table 5. Relative abundance (concentration, $\mu \mathrm{g} / \mathrm{kg}$ ) of selected volatiles in liquid Mozzarella retentate stored for $0,6,12,24$, and $48 \mathrm{~h}$

\begin{tabular}{lccccc}
\hline & \multicolumn{5}{c}{ Storage time } \\
\cline { 2 - 6 } Compound & $0 \mathrm{~h}$ & $6 \mathrm{~h}$ & $12 \mathrm{~h}$ & $24 \mathrm{~h}$ & $48 \mathrm{~h}$ \\
\hline Diacetyl & $0.49^{\mathrm{a}}$ & $0.25^{\mathrm{b}}$ & $0.20^{\mathrm{b}}$ & $0.20^{\mathrm{b}}$ & $0.07^{\mathrm{b}}$ \\
Butanal & $1.22^{\mathrm{a}}$ & $1.87^{\mathrm{a}}$ & $1.91^{\mathrm{a}}$ & $2.01^{\mathrm{a}}$ & $1.61^{\mathrm{a}}$ \\
Hexanal & $0.15^{\mathrm{b}}$ & $0.20^{\mathrm{b}}$ & $0.99^{\mathrm{b}}$ & $1.26^{\mathrm{b}}$ & $11.79^{\mathrm{a}}$ \\
Heptanal & $0.03^{\mathrm{b}}$ & $0.08^{\mathrm{b}}$ & $0.05^{\mathrm{b}}$ & $0.16^{\mathrm{b}}$ & $1.07^{\mathrm{a}}$ \\
Octanal & $0.12^{\mathrm{a}}$ & $0.11^{\mathrm{a}}$ & $0.11^{\mathrm{a}}$ & $0.13^{\mathrm{a}}$ & $0.12^{\mathrm{a}}$ \\
Decanal & $\mathrm{ND}^{1}$ & $0.01^{\mathrm{a}}$ & $0.01^{\mathrm{a}}$ & $N D$ & $0.01^{\mathrm{a}}$ \\
Total aldehydes & $1.52^{\mathrm{b}}$ & $2.26^{\mathrm{b}}$ & $3.06^{\mathrm{b}}$ & $3.57^{\mathrm{b}}$ & $14.61^{\mathrm{a}}$ \\
\hline
\end{tabular}

${ }^{\mathrm{a}, \mathrm{b}}$ Means within rows followed by different letters are different $(P<0.05)$.

${ }^{1} \mathrm{ND}=$ not detected

Cabbage and potato flavors have been previously associated with Cheddar-sourced WPC80 and WPI (Wright et al., 2006, 2009) and may be due to make-procedure and starter culture or to whey protein processing steps (such as bleaching) that are specific to Cheddar whey.

Tomaino et al. (2004) reported VLOP compounds in liquid Cheddar whey and hypothesized that, because these compounds were common VLOP, their presence indicated that oxidation occurred during cheese making or whey pasteurization. Two storage studies reported similar increases of hexanal concentration in liquid whey and WPC after 6 and $14 \mathrm{~d}$ of storage (Tomaino et al., 2004). However, few studies have actually documented sensory and volatile compound analysis in both liquid and spray-dried whey products and fewer still, to our knowledge, have followed volatile compounds and sensory profiles from fluid whey through processing and into spray-dried products in a controlled pilot-plant study. Croissant et al. (2009) evaluated the effect of bleaching on flavor of liquid whey and WPC66 manufactured from the same liquid whey. They documented volatile compounds and sensory changes in fluid whey that were consistent with the volatile compounds and sensory profile of the spray-dried WPC66, suggesting that observations from fluid whey are indicative of the quality of the final spray-dried product. More recently, Campbell et al. (2011) compared WPC from rennet set whey and WPC from mesophilic (Cheddar) starter.

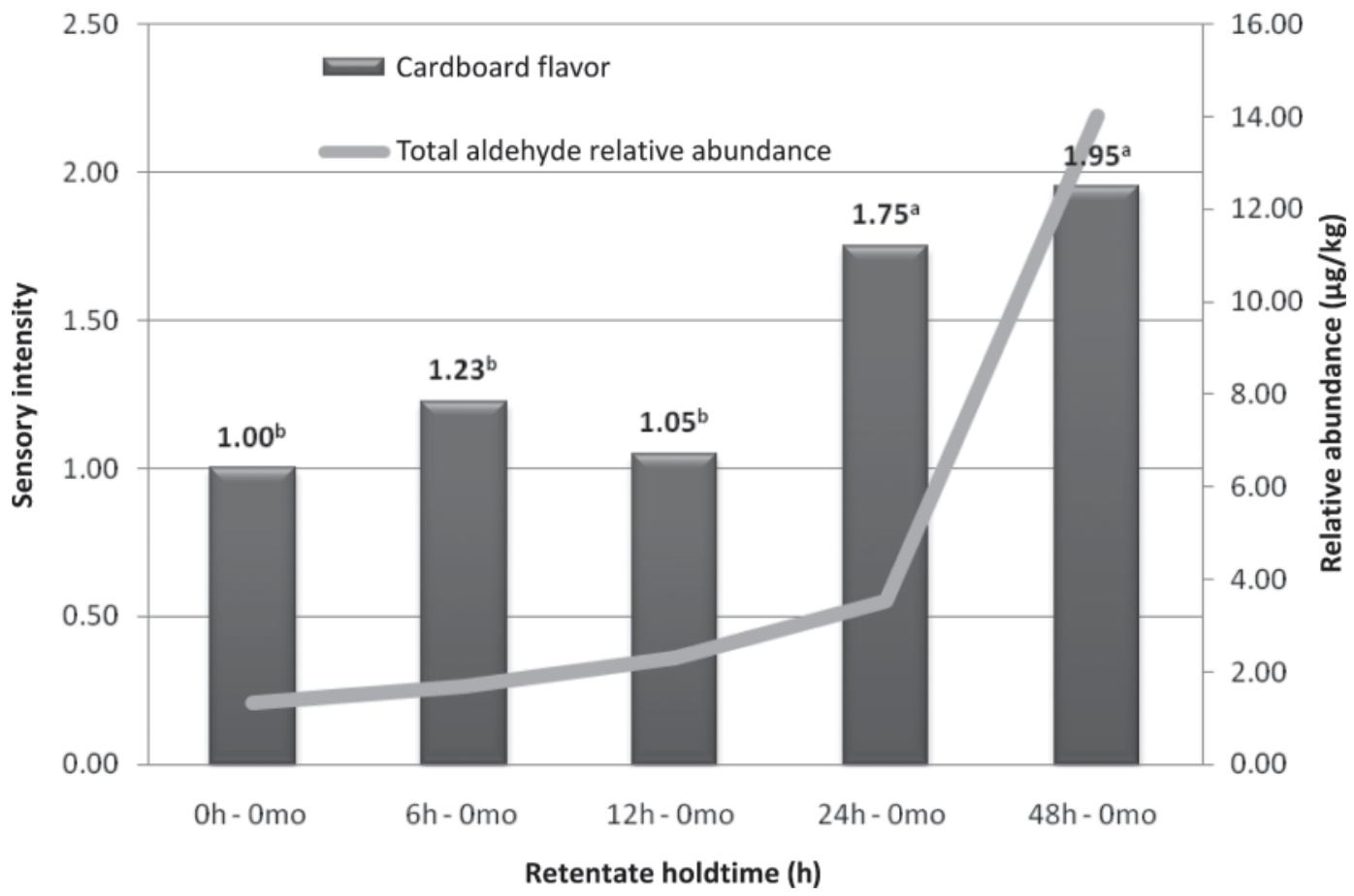

Figure 3. Comparison of cardboard flavor intensity to solid-phase microextraction total aldehyde relative abundance ( $\mu \mathrm{g} / \mathrm{kg})$ in Mozzarella whey protein concentrate (WPC80) from liquid retentate stored for $0,6,12,24$, or $48 \mathrm{~h}$. Means followed by different superscripts are different $(P<0.05)$. 
Table 6. Relative abundance (concentration, $\mu \mathrm{g} / \mathrm{kg}$ ) of selected volatiles in liquid Cheddar retentate stored for $0,6,12,24$, and $48 \mathrm{~h}^{1}$

\begin{tabular}{lccccc}
\hline & \multicolumn{5}{c}{ Storage time } \\
\cline { 2 - 6 } Compound $^{2}$ & $0 \mathrm{~h}$ & $6 \mathrm{~h}$ & $12 \mathrm{~h}$ & $24 \mathrm{~h}$ & $48 \mathrm{~h}$ \\
\hline Diacetyl & 0.22 & 0.26 & 0.26 & 0.23 & 0.19 \\
Dimethyl disulfide & 2.84 & 4.36 & 4.98 & 9.34 & 2.34 \\
Hexanal & 7.69 & 6.58 & 7.98 & 6.79 & 5.51 \\
Heptanal & 0.30 & 0.38 & 0.42 & 0.37 & 0.27 \\
Dimethyl trisulfide & 0.47 & 0.81 & 0.95 & 1.34 & 0.56 \\
Octanal & 0.07 & 0.07 & 0.07 & 0.07 & 0.05 \\
Nonanal & 0.12 & 0.32 & 0.35 & 0.20 & 0.15 \\
Total aldehydes & 8.18 & 7.36 & 8.83 & 7.43 & 5.97 \\
\hline
\end{tabular}

${ }^{1}$ All means within rows were not different $(P>0.05)$.

${ }^{2} \mathrm{~A}$ peak for butanal could not be integrated and as such was considered not detected.

Lipid oxidation compounds were higher $(P<0.05)$ in WPC manufactured from whey with starter culture compared with WPC from rennet-set whey. Once again, these results suggest that the starter culture is the source of many flavor compounds, including directly or indirectly a source of lipid oxidation compounds.

The importance of these VLOP observations lies in their effect on flavor. Lipid oxidation products have been associated with cardboard flavor in dried whey proteins, which is the off-flavor most commonly attributed to decreased quality in whey (Drake et al., 2003; Whitson et al., 2010). In the current study, volatile compound changes were observed in Mozzarella re- tentate, but not in Cheddar retentate, which could be attributed to processing or compositional differences. Additionally, the lipid concentration of the Mozzarella retentate was higher than that of the Cheddar retentate (1.35 vs. 0.06$)$ and this difference could certainly affect total aldehyde concentrations. Because lipid oxidation is the primary reaction that produces aldehydes, then initial lipid content as well as lipid quality (oleic vs. linoleic content) plays a role in the final types of aldehydes and concentrations produced. Once produced, some aldehydes are much more unstable than others, and readily degrade into other aldehydes (Frankel, 2005). For example, nonanal is produced from the 9-

Table 7. Relative abundance (concentration, $\mu \mathrm{g} / \mathrm{kg}$ ) of selected volatile lipid oxidation products in Mozzarella whey protein concentrate from liquid retentate stored for $0,6,12,24$, or $48 \mathrm{~h}$ across 12 mo of storage at $21^{\circ} \mathrm{C}(0,4,8$, or $12 \mathrm{mo})$

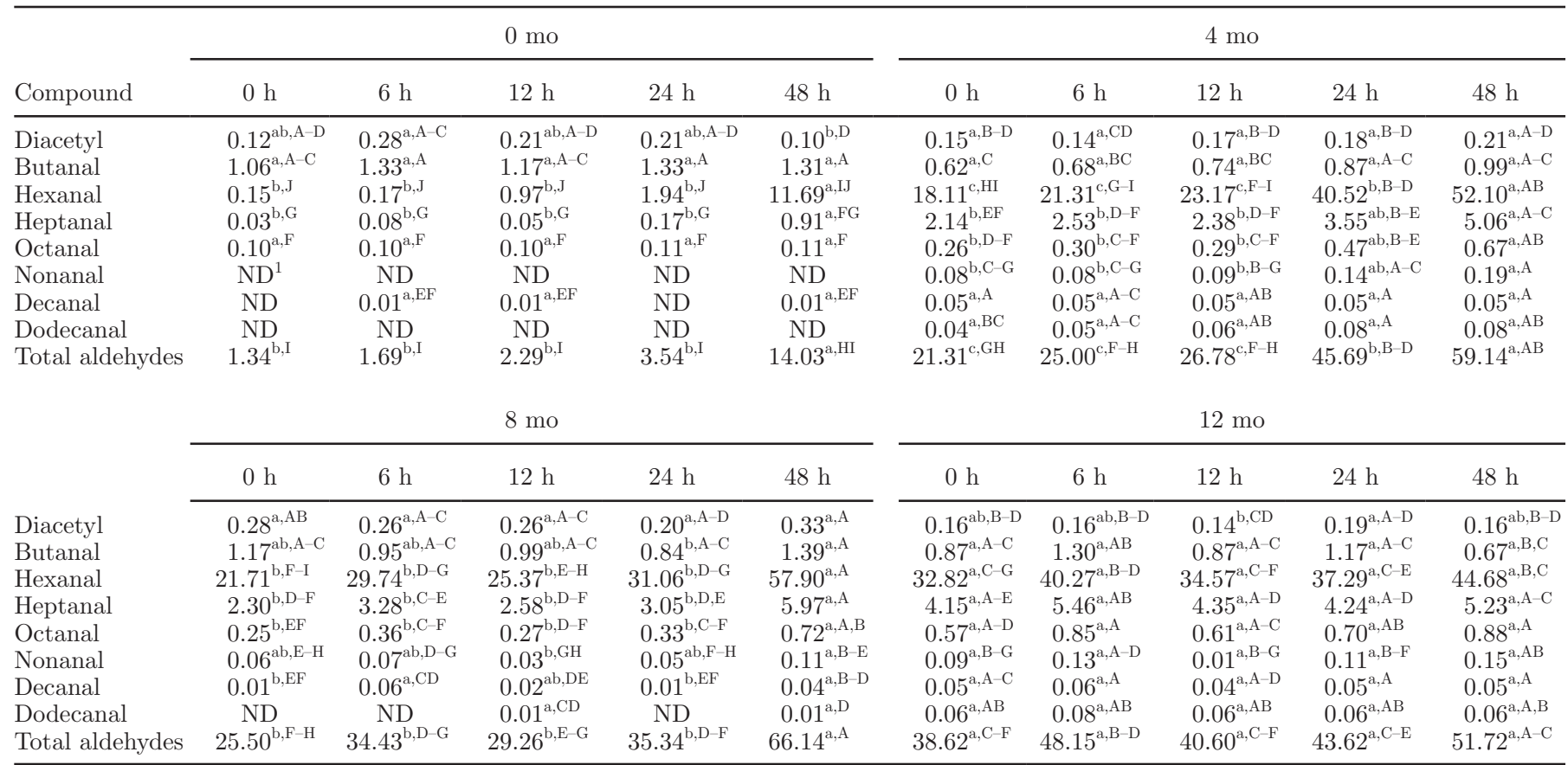

${ }^{\mathrm{a}-\mathrm{c}}$ Means in rows followed by different lowercase letters are different within storage month time point $(P<0.05)$.

${ }^{\mathrm{A}-\mathrm{J}}$ Means in rows followed by different uppercase letters are different within the overall 12-mo storage period $(P<0.05)$.

${ }^{1} \mathrm{ND}=$ not detected. 
Table 8. Relative abundance (concentration, $\mu \mathrm{g} / \mathrm{kg}$ ) of select volatile lipid oxidation products in Cheddar whey protein isolate from liquid retentate stored for $0,6,12,24$, or 48 $\mathrm{h}$ across $12 \mathrm{mo}$ of storage at $21^{\circ} \mathrm{C}(0,4,8$, or $12 \mathrm{mo})$

\begin{tabular}{|c|c|c|c|c|c|c|c|c|c|c|}
\hline \multirow[b]{2}{*}{ Compound } & \multicolumn{5}{|c|}{$0 \mathrm{mo}$} & \multicolumn{5}{|c|}{$4 \mathrm{mo}$} \\
\hline & $0 \mathrm{~h}$ & $6 \mathrm{~h}$ & $12 \mathrm{~h}$ & $24 \mathrm{~h}$ & $48 \mathrm{~h}$ & $0 \mathrm{~h}$ & $6 \mathrm{~h}$ & $12 \mathrm{~h}$ & $24 \mathrm{~h}$ & $48 \mathrm{~h}$ \\
\hline Diacetyl & $0.23^{\mathrm{a}, \mathrm{D}}$ & $0.30^{\mathrm{a}, \mathrm{CD}}$ & $0.33^{\mathrm{a}, \mathrm{B}-\mathrm{D}}$ & $0.30^{\mathrm{a}, \mathrm{CD}}$ & $0.26^{\mathrm{a}, \mathrm{D}}$ & $0.45^{\mathrm{a}, \mathrm{A}-\mathrm{D}}$ & $0.53^{\mathrm{a}, \mathrm{AB}}$ & $0.59^{\mathrm{a}, \mathrm{A}}$ & $0.56^{\mathrm{a}, \mathrm{A}, \mathrm{B}}$ & $0.59^{\mathrm{a}, \mathrm{A}}$ \\
\hline Dimethyl disulfide & $3.41^{\mathrm{b}, \mathrm{H}}$ & $6.47^{\mathrm{b}, \mathrm{H}}$ & $7.78^{\mathrm{ab}, \mathrm{H}}$ & $11.97^{\mathrm{a}, \mathrm{GH}}$ & $6.36^{\mathrm{b}, \mathrm{H}}$ & $14.24^{\mathrm{b}, \mathrm{F}-\mathrm{H}}$ & $18.91^{\mathrm{ab}, \mathrm{E}-\mathrm{H}}$ & $20.52^{\mathrm{ab}, \mathrm{D}-\mathrm{H}}$ & $28.64^{\mathrm{a}, \mathrm{C}-\mathrm{G}}$ & $20.36^{\mathrm{ab}, \mathrm{D}-\mathrm{H}}$ \\
\hline Hexanal & $5.42^{\mathrm{a}, \mathrm{A}-\mathrm{C}}$ & $5.71^{\mathrm{a}, \mathrm{A}-\mathrm{C}}$ & $5.30^{\mathrm{a}, \mathrm{A}-\mathrm{C}}$ & $6.24^{\mathrm{a}, \mathrm{A}-\mathrm{C}}$ & $5.73^{\mathrm{a}, \mathrm{A}-\mathrm{C}}$ & $6.97^{\mathrm{a}, \mathrm{A}, \mathrm{B}}$ & $9.95^{\mathrm{a}, \mathrm{A}}$ & $6.32^{\mathrm{a}, \mathrm{A}-\mathrm{C}}$ & $6.16^{\mathrm{a}, \mathrm{A}-\mathrm{C}}$ & $6.48^{\mathrm{a}, \mathrm{A}-\mathrm{C}}$ \\
\hline Heptanal & $0.26^{\mathrm{a}, \mathrm{C}}$ & $0.39^{\mathrm{a}, \mathrm{BC}}$ & $0.38^{\mathrm{a}, \mathrm{BC}}$ & $0.37^{\mathrm{a}, \mathrm{BC}}$ & $0.42^{\mathrm{a}, \mathrm{B}, \mathrm{C}}$ & $0.52^{\mathrm{a}, \mathrm{A}-\mathrm{C}}$ & $0.82^{\mathrm{a}, \mathrm{A}}$ & $0.61^{\mathrm{a}, \mathrm{A}, \mathrm{B}}$ & $0.53^{\mathrm{a}, \mathrm{A}-\mathrm{C}}$ & $0.54^{\mathrm{a}, \mathrm{A}-\mathrm{C}}$ \\
\hline Dimethyl trisulfide & $0.51^{\mathrm{b}, \mathrm{F}}$ & $0.98^{\mathrm{ab}, \mathrm{D}-\mathrm{F}}$ & $1.15^{\mathrm{ab}, \mathrm{D}-\mathrm{F}}$ & $1.54^{\mathrm{a}, \mathrm{C}-\mathrm{F}}$ & $0.91^{\mathrm{ab}, \mathrm{EF}}$ & $1.76^{\mathrm{a}, \mathrm{B}-\mathrm{E}}$ & $2.56^{\mathrm{a}, \mathrm{A}-\mathrm{C}}$ & $2.61^{\mathrm{a}, \mathrm{A}-\mathrm{C}}$ & $3.33^{\mathrm{a}, \mathrm{A}}$ & $2.62^{\mathrm{a}, \mathrm{A}-\mathrm{C}}$ \\
\hline Octanal & $0.07^{\mathrm{b}, \mathrm{C}}$ & $0.09^{\mathrm{ab}, \mathrm{C}}$ & $0.09^{\mathrm{ab}, \mathrm{C}}$ & $0.08^{\mathrm{ab}, \mathrm{C}}$ & $0.13^{\mathrm{a}, \mathrm{B}, \mathrm{C}}$ & $0.15^{\mathrm{a}, \mathrm{A}-\mathrm{C}}$ & $0.23^{\mathrm{a}, \mathrm{A}}$ & $0.19^{\mathrm{a}, \mathrm{AB}}$ & $0.16^{\mathrm{a}, \mathrm{A}-\mathrm{C}}$ & $0.11^{\mathrm{a}, \mathrm{BC}}$ \\
\hline Nonanal & $0.14^{\mathrm{b}, \mathrm{F}}$ & $0.38^{\mathrm{ab}, \mathrm{B}-\mathrm{F}}$ & $0.42^{\mathrm{a}, \mathrm{B}-\mathrm{E}}$ & $0.27^{\mathrm{ab}, \mathrm{D}-\mathrm{F}}$ & $0.47^{\mathrm{a}, \mathrm{B}-\mathrm{E}}$ & $0.57^{\mathrm{a}, \mathrm{b}, \mathrm{A}-\mathrm{C}}$ & $0.62^{\mathrm{ab}, \mathrm{AB}}$ & $0.82^{\mathrm{a}, \mathrm{A}}$ & $0.51^{\mathrm{ab}, \mathrm{B}-\mathrm{D}}$ & $0.36^{\mathrm{b}, \mathrm{B}-\mathrm{F}}$ \\
\hline \multirow[t]{3}{*}{ Total aldehyde } & $5.89^{\mathrm{a}, \mathrm{A}-\mathrm{D}}$ & $6.57^{\mathrm{a}, \mathrm{A}-\mathrm{D}}$ & $6.19^{\mathrm{a}, \mathrm{A}-\mathrm{D}}$ & $6.95^{\mathrm{a}, \mathrm{A}-\mathrm{D}}$ & $6.75^{\mathrm{a}, \mathrm{A}-\mathrm{D}}$ & $8.21^{\mathrm{a}, \mathrm{AB}}$ & $11.62^{\mathrm{a}, \mathrm{A}}$ & $7.94^{\mathrm{a}, \mathrm{A}-\mathrm{C}}$ & $7.36^{\mathrm{a}, \mathrm{A}-\mathrm{D}}$ & $7.49^{\mathrm{a}, \mathrm{A}-\mathrm{D}}$ \\
\hline & \multicolumn{5}{|c|}{$8 \mathrm{mo}$} & \multicolumn{5}{|c|}{$12 \mathrm{mo}$} \\
\hline & $0 \mathrm{~h}$ & $6 \mathrm{~h}$ & $12 \mathrm{~h}$ & $24 \mathrm{~h}$ & $48 \mathrm{~h}$ & $0 \mathrm{~h}$ & $6 \mathrm{~h}$ & $12 \mathrm{~h}$ & $24 \mathrm{~h}$ & $48 \mathrm{~h}$ \\
\hline Diacetyl & $0.57^{\mathrm{a}, \mathrm{A}}$ & $0.56^{\mathrm{a}, \mathrm{AB}}$ & $0.46^{\mathrm{a}, \mathrm{A}-\mathrm{D}}$ & $0.48^{\mathrm{a}, \mathrm{A}-\mathrm{D}}$ & $0.50^{\mathrm{a}, \mathrm{A}-\mathrm{C}}$ & $0.35^{\mathrm{a}, \mathrm{A}-\mathrm{D}}$ & $0.49^{\mathrm{a}, \mathrm{A}-\mathrm{D}}$ & $0.36^{\mathrm{a}, \mathrm{A}-\mathrm{D}}$ & $0.21^{\mathrm{a}, \mathrm{D}}$ & $0.47^{\mathrm{a}, \mathrm{A}-\mathrm{D}}$ \\
\hline Dimethyl disulfide & $30.63^{\mathrm{a}, \mathrm{C}-\mathrm{F}}$ & $33.49^{\mathrm{a}, \mathrm{B}-\mathrm{E}}$ & $36.68^{\mathrm{a}, \mathrm{A}-\mathrm{E}}$ & $47.25^{\mathrm{a}, \mathrm{A}-\mathrm{C}}$ & $29.14^{\mathrm{a}, \mathrm{C}-\mathrm{G}}$ & $39.79^{\mathrm{b}, \mathrm{A}-\mathrm{E}}$ & $56.49^{\mathrm{ab}, \mathrm{AB}}$ & $58.43^{\mathrm{a}, \mathrm{A}}$ & $58.40^{\mathrm{a}, \mathrm{A}}$ & $41.21^{\mathrm{b}, \mathrm{A}-\mathrm{D}}$ \\
\hline Hexanal & $6.71^{\mathrm{a}, \mathrm{A}-\mathrm{C}}$ & $4.84^{\mathrm{a}, \mathrm{A}-\mathrm{C}}$ & $4.32^{\mathrm{a}, \mathrm{BC}}$ & $5.23^{\mathrm{a}, \mathrm{A}-\mathrm{C}}$ & $4.99^{\mathrm{a}, \mathrm{A}-\mathrm{C}}$ & $0.31^{\mathrm{ab}, \mathrm{C}}$ & $1.75^{\mathrm{a}, \mathrm{BC}}$ & $0.71^{\mathrm{ab}, \mathrm{BC}}$ & $0.26^{\mathrm{b}, \mathrm{C}}$ & $0.30^{\mathrm{ab}, \mathrm{C}}$ \\
\hline Heptanal & $0.59^{\mathrm{a}, \mathrm{AB}}$ & $0.54^{\mathrm{a}, \mathrm{A}-\mathrm{C}}$ & $0.52^{\mathrm{a}, \mathrm{A}-\mathrm{C}}$ & $0.50^{\mathrm{a}, \mathrm{A}-\mathrm{C}}$ & $0.47^{\mathrm{a}, \mathrm{BC}}$ & $0.29^{\mathrm{a}, \mathrm{B}, \mathrm{C}}$ & $0.28^{\mathrm{a}, \mathrm{BC}}$ & $0.32^{\mathrm{a}, \mathrm{BC}}$ & $0.27^{\mathrm{a}, \mathrm{BC}}$ & $0.24^{\mathrm{a}, \mathrm{C}}$ \\
\hline Dimethyl trisulfide & $1.72^{\mathrm{b}, \mathrm{B}-\mathrm{E}}$ & $2.62^{\mathrm{ab}, \mathrm{A}-\mathrm{C}}$ & $2.77^{\mathrm{a}, \mathrm{A}, \mathrm{B}}$ & $3.11^{\mathrm{a}, \mathrm{A}}$ & $2.54^{\mathrm{ab}, \mathrm{A}-\mathrm{C}}$ & $2.28^{\mathrm{a}, \mathrm{A}-\mathrm{E}}$ & $3.55^{\mathrm{a}, \mathrm{A}}$ & $3.28^{\mathrm{a}, \mathrm{A}}$ & $3.54^{\mathrm{a}, \mathrm{A}}$ & $2.40^{\mathrm{a}, \mathrm{A}-\mathrm{D}}$ \\
\hline Octanal & $0.19^{\mathrm{a}, \mathrm{A}, \mathrm{B}}$ & $0.14^{\mathrm{ab}, \mathrm{BC}}$ & $0.12^{\mathrm{ab}, \mathrm{BC}}$ & $0.12^{\mathrm{ab}, \mathrm{BC}}$ & $0.10^{\mathrm{b}, \mathrm{BC}}$ & $0.07^{\mathrm{a}, \mathrm{C}}$ & $0.06^{\mathrm{bc}, \mathrm{C}}$ & $0.07^{\mathrm{ab}, \mathrm{C}}$ & $0.06^{\mathrm{a}-\mathrm{c}, \mathrm{C}}$ & $0.05^{\mathrm{c}, \mathrm{C}}$ \\
\hline Nonanal & $0.24^{\mathrm{a}, \mathrm{D}-\mathrm{F}}$ & $0.32^{\mathrm{a}, \mathrm{C}-\mathrm{F}}$ & $0.41^{\mathrm{a}, \mathrm{B}-\mathrm{F}}$ & $0.19^{\mathrm{a}, \mathrm{EF}}$ & $0.23^{\mathrm{a}, \mathrm{D}-\mathrm{F}}$ & $0.16^{\mathrm{ab}, \mathrm{EF}}$ & $0.22^{\mathrm{a}, \mathrm{D}-\mathrm{F}}$ & $0.21^{\mathrm{a}, \mathrm{D}-\mathrm{F}}$ & $0.15^{\mathrm{bc}, \mathrm{EF}}$ & $0.10^{\mathrm{c}, \mathrm{F}}$ \\
\hline Total aldehyde & $7.23^{\mathrm{a}, \mathrm{A}-\mathrm{D}}$ & $5.83^{\mathrm{a}, \mathrm{A}-\mathrm{D}}$ & $5.37^{\mathrm{a}, \mathrm{B}-\mathrm{D}}$ & $6.04^{\mathrm{a}, \mathrm{A}-\mathrm{D}}$ & $5.79^{\mathrm{a}, \mathrm{A}-\mathrm{D}}$ & $0.82^{\mathrm{b}, \mathrm{CD}}$ & $2.31^{\mathrm{a}, \mathrm{B}-\mathrm{D}}$ & $1.32^{\mathrm{ab}, \mathrm{B}-\mathrm{D}}$ & $0.74^{\mathrm{b}, \mathrm{D}}$ & $0.70^{\mathrm{b}, \mathrm{D}}$ \\
\hline
\end{tabular}

${ }^{\mathrm{a}-\mathrm{c}}$ Means in rows followed by different lowercase letters are different within storage month time point $(P<0.05)$.

${ }^{\mathrm{A}-\mathrm{H}} \mathrm{Means}$ in rows followed by different uppercase letters are different within the overall 12-mo storage period $(P<0.05)$. 


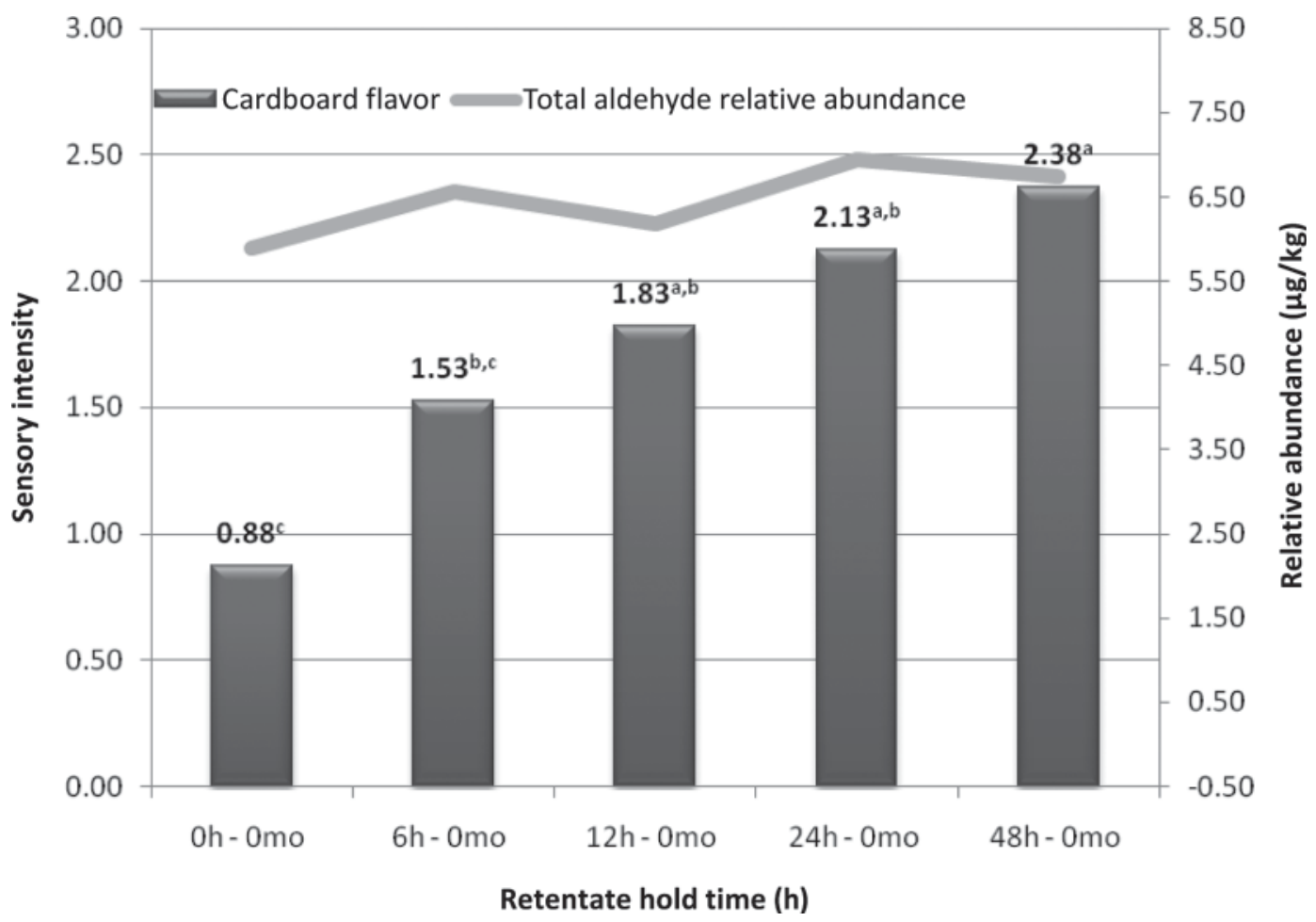

Figure 4. Comparison of descriptive analysis cardboard flavor intensity to solid-phase microextraction total aldehyde relative abundance $(\mu \mathrm{g} / \mathrm{kg})$ in Cheddar whey protein isolate from liquid retentate stored for $0,6,12,24$, or $48 \mathrm{~h}$. Means followed by different superscripts indicate differences $(P<0.05)$ among hold times.

and 10-hydroperoxide of oleate. In a circumstance such as whey protein, where 8-, 9-, 10-, and 11-oxo esters of oleate are present in a mixture, different lipid oxidation mechanisms determine the final aldehyde ratio. Photosensitized lipid oxidation, compared with autoxidation, favors cleavage of the 9- and 10-hydroperoxides, and thus increases the concentration of nonanal (Frankel, 2005). A subsequent decrease in nonanal concentration could be due to oxidation of the aldehyde. As lipid oxidation advances and saturated aldehydes accumulate, unsaturated aldehydes are favored to oxidize into lower aldehydes and dialdehydes (Frankel, 2005). A large increase in the hexanal concentration of Mozzarella liquid retentate from 24 to $48 \mathrm{~h}$ could be attributed to the multiple lipid oxidation pathways that produce hexanal, including direct hydroxide cleavage and aldehyde degradation (Frankel, 2005). These various lipid oxidation pathways could also explain why hexanal and heptanal were observed at higher initial concentrations in Cheddar retentate than in Mozzarella retentate. Fatty acid composition, starter cultures, and processing parameters are all additional points of variability between Cheddar and Mozzarella retentate that could translate into VLOP variability (Liaw et al., 2010).

SPME GC-MS of Spray-Dried WPC80 and WPI. Spray-dried Mozzarella WPC80 followed similar volatile trends as Mozzarella liquid retentates. Hexanal, heptanal, and total aldehyde relative abundances increased as retentate hold time increased (Table 7). No discernable trend was observed for other aldehydes at 0 mo. Unlike liquid retentate, spray-dried Cheddar WPI headspace volatiles changed with increased retentate storage time, consistent with sensory changes. Changes were documented for dimethyl disulfide, dimethyl trisulfide, octanal, and nonanal (Table 8). Octanal and nonanal and dimethyl trisulfide increased in WPI with increased retentate storage time. Dimethyl disulfide increased and then decreased with increased retentate storage time.

Tomaino et al. (2004) hypothesized that because liquid whey was often transported and stored before drying, reactions that take place during this time could dramatically affect the flavor of the finished whey powder after concentration and drying. Volatile compounds present in liquid whey have been shown to be retained during spray drying (Bangs and Reineccius, 1981), which could be attributed to binding of proteins and flavor compounds such as methyl ketones and aldehydes (lipid oxidation products). Our results are consistent with these hypotheses. Oxidation products are produced during storage, and these products are carried through to the finished whey powder, affecting its flavor (Wright et al., 2009; Evans et al., 2010). 


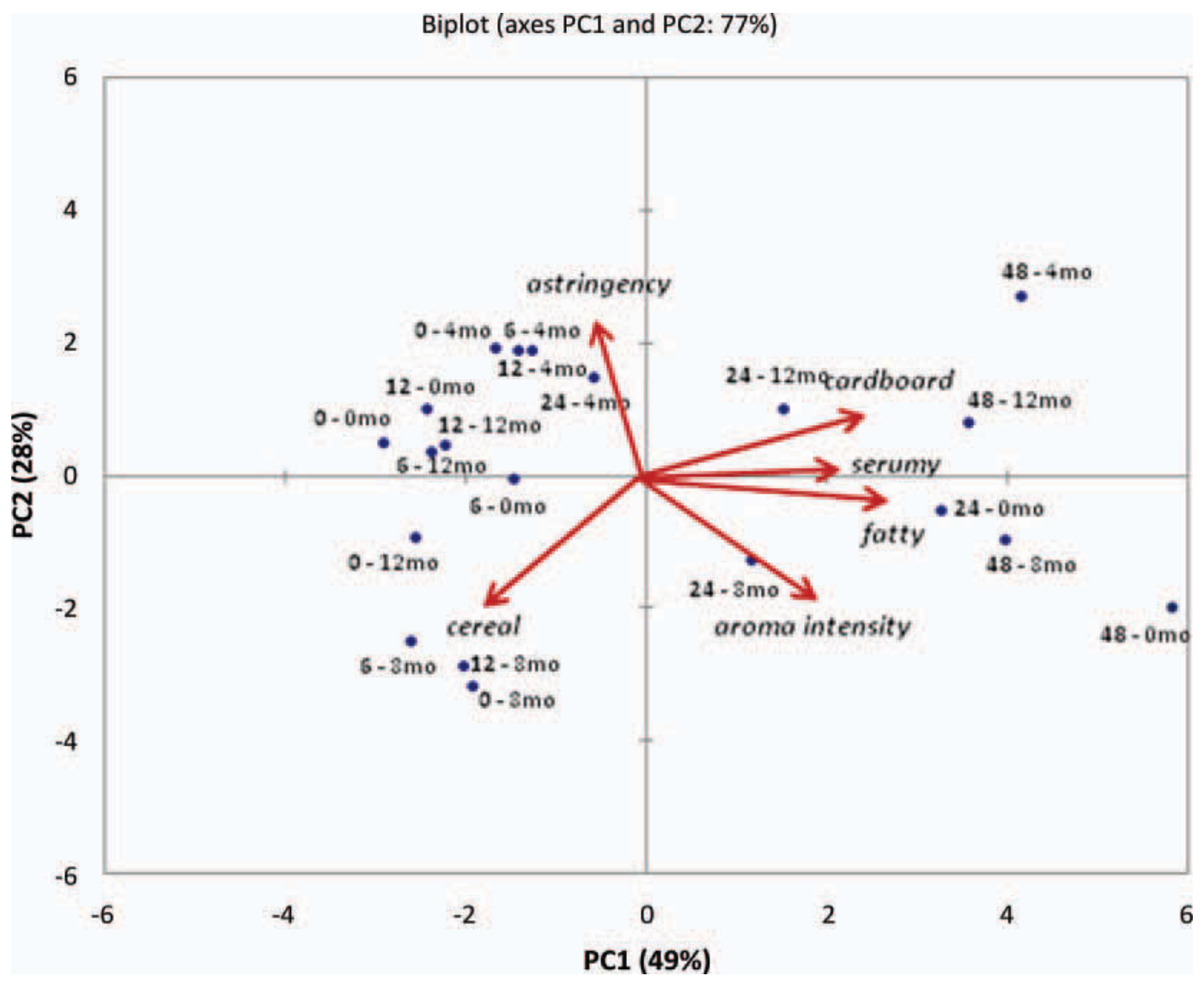

Figure 5. Descriptive sensory analysis principal component (PC) biplot of Mozzarella whey protein concentrate (WPC80) from liquid retentate stored for $0,6,12,24$, or $48 \mathrm{~h}$ across 12 mo of storage at $21^{\circ} \mathrm{C}(0,4,8$, or $12 \mathrm{mo})$. For data point labels, the first number is the retentate storage time and the second number is WPC80 storage time. Color version available in the online PDF.

Not all VLOP are formed from the same pathway nor do they appear at the same rate (Marsili, 1999; Lee and Min, 2009). Milkfat is composed of approximately $25 \%$ oleic acid and only $2 \%$ linoleic acid; however, the phospholipid component of the milkfat globule membrane is $6 \%$ linoleic acid (Frankel, 2005) and this fraction is enriched in whey proteins. When autooxidized, oleate forms 8-, 9-, 10-, and 11-hydroperoxides, which are further cleaved on the ester side to produce heptanal, octanal, nonanal, and decanal aldehydes, respectively. Autooxidized linoleate forms 9- and 13-hydroperoxides that are cleaved to produce 2,4 decadienal, pentanal, and hexanal. Additional hexanal is produced through the cleavage of the 12-hydroperoxide formed from photooxidized linoleic acid (Frankel, 2005). The reaction rate of linoleic acid is 40 times that of oleic acid (Frankel, 2005). Further oxidation and breakdown of unsaturated aldehydes can also yield hexanal. These multiple pathways resulting in hexanal production and the reaction kinetics of lipid oxidation explain why hexanal was the primary aldehyde observed at the highest concentration.
Direct comparison of sensory perception of cardboard flavor and the relative abundance of total aldehydes clearly indicated an increasing trend for both flavor and aldehyde concentration as retentate hold time increased for both whey types (Figures 3 and 4). Sensory and volatile results substantiate the hypothesis that as whey retentate is held for extended times before spray drying, lipid oxidation reactions may lead to increased production of off-flavors that alter the clean flavor profile expected of whey protein powders.

Shelf Life of WPC80 and WPI. When whey is utilized in the industry, it is rarely used immediately after manufacture. Thus, the powders were evaluated every 4 mo for 12 mo. Mozzarella WPC 80 with a retentate hold time of $48 \mathrm{~h}$ had higher intensities of cardboard, serumy, fatty, and aroma intensity attributes compared with WPC80 with retentate hold times of $12 \mathrm{~h}$ or less across 12 mo of storage (Figure 5). Cheddar WPI from retentate held for $48 \mathrm{~h}$ also indicated increased intensities of cardboard, cabbage, potato, chlorine, and aroma flavor attributes, even after 12 mo of WPI storage, compared with Cheddar WPI retentate held for 
Biplot (axes PC1 and PC2: 85\%)

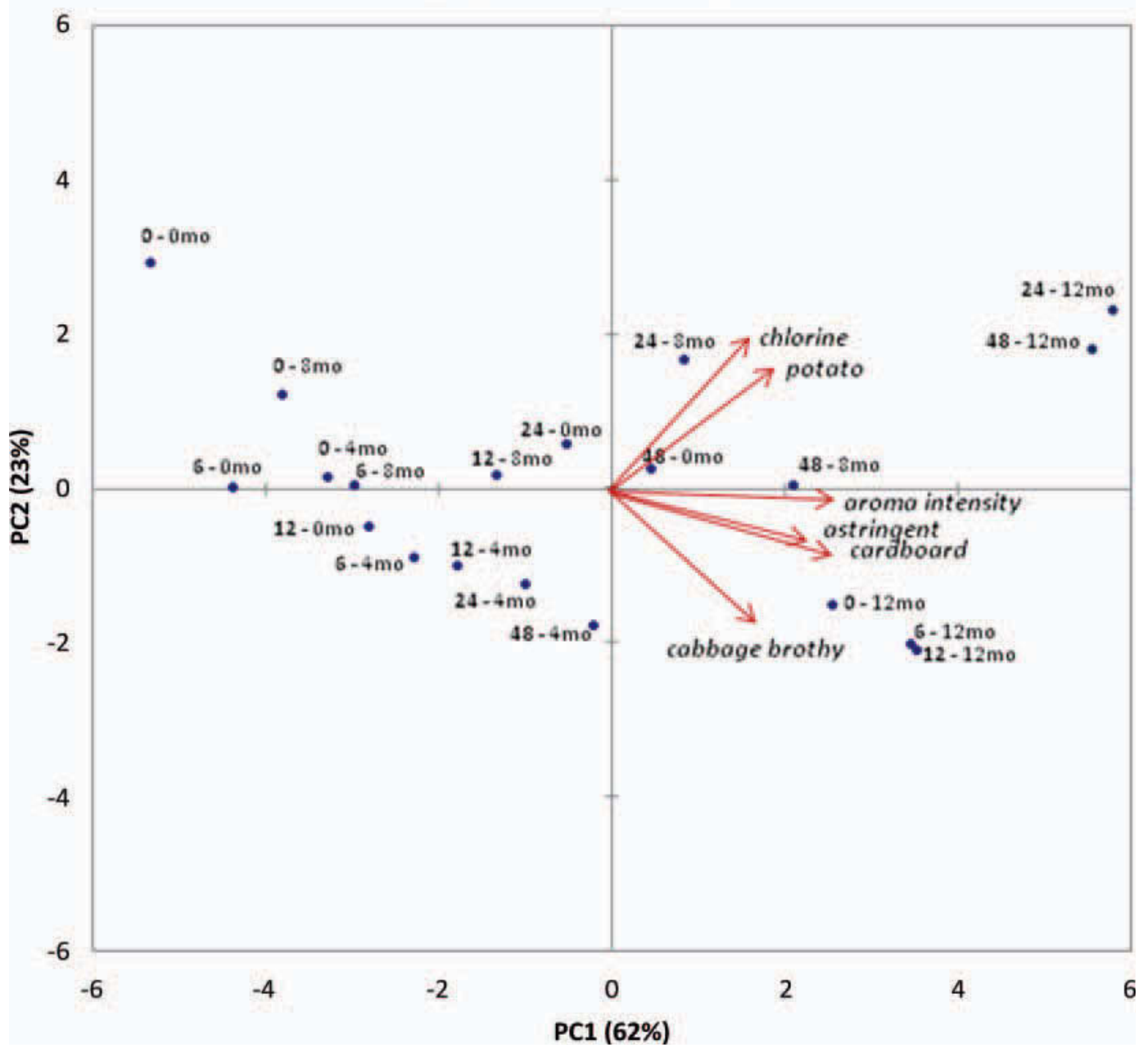

Figure 6. Descriptive sensory analysis principal component (PC) biplot of Cheddar whey protein isolate (WPI) from liquid retentate stored for $0,6,12,24$, or $48 \mathrm{~h}$ across 12 mo storage at $21^{\circ} \mathrm{C}(0,4,8$, or $12 \mathrm{mo})$. For data point labels, the first number is the retentate storage time and the second number is WPI storage time. Color version available in the online PDF.

$0 \mathrm{~h}$ (Figure 6). This indicates that although the $0 \mathrm{~h}$ sample was the blandest sample for both whey proteins initially, it was also the blandest sample (according to off-flavor development) following 12 mo of storage.

Volatile analysis of spray-dried Mozzarella WPC80 and Cheddar WPI showed differences between retentate hold times throughout the 12-mo shelf life (Tables 7 and 8 ). Total aldehyde relative abundance was highest at $48 \mathrm{~h}$ retentate storage for each time point for Mozzarella WPC80. Sulfur degradation compounds were highest at 12,24 , and $48 \mathrm{~h}$ of retentate storage for each time point for Cheddar WPI.

Alterations in the flavor profiles of whey proteins are very important factors for ingredient applications. Previously, off-flavors in milk powder were shown to carry through into ingredient applications and have a negative effect on consumers (Caudle et al., 2005). Similar results have been reported for WPC80 and WPI in beverage applications (Drake, 2006; Drake et al., 2009a,b; Wright et al., 2009; Evans et al., 2010). Childs et al. (2007) evaluated the consumer acceptance of meal replacement bars and beverages containing soy and whey protein. Consumers preferred whey protein applications to soy applications; however, they disliked both. Furthermore, Wright et al. (2009) evaluated consumer acceptance of peach-flavored beverages with $6 \%$ added whey protein. Acceptance of WPC80 peach beverages decreased when WPC80 was stored before incorporation into beverages. Similar results were documented for WPI beverages when WPI was stored for as 
little as 9 mo. Stronger flavors in whey proteins mean greater potential for flavor carry-through into ingredient applications.

\section{CONCLUSIONS}

During liquid storage of whey protein retentate at $3^{\circ} \mathrm{C}$ chemical reactions continue to occur that produce off-flavors in the retentates and spray-dried whey protein. Concurrent with sensory results, lipid oxidation products (octanal) and sulfur degradation products (dimethyl disulfide, dimethyl trisulfide) increased in spray-dried Cheddar products with increased liquid retentate storage time. Total relative abundances of aldehydes (butanal, hexanal, heptanal, octanal, nonanal) in spray-dried Mozzarella WPC80 increased with increasing liquid retentate hold time. Shelf stability, as evaluated by sensory and volatile compound analyses, was decreased in spray-dried products that had longer retentate hold times. It is critical for processors to reduce intermediate storage time in the liquid state as they process raw whey into WPC80 or WPI. By so doing, they can dramatically improve the flavor of whey protein products. For maximum quality and shelf life, liquid retentate should be held for less than $12 \mathrm{~h}$ before spray drying.

\section{ACKNOWLEDGMENTS}

Funding was provided, in part, by the Dairy Research Institute (Rosemont, IL). The use of trade names in the publication does not imply endorsement by these organizations or criticisms of ones not mentioned.

\section{REFERENCES}

Bangs, W. E., and G. A. Reineccius. 1981. Influence of dryer infeed matrices on the retention of volatile flavor compounds during sray drying. J. Food Sci. 47:254-259.

Campbell, R. E., R. E. Miracle, and M. A. Drake. 2011. The impact of starter culture and annatto on the flavor and functionality of whey protein concentrate. J. Dairy Sci. 94:1185-1193.

Carunchia Whetstine, M. E., A. E. Croissant, and M. A. Drake. 2005. Characterization of dried whey protein concentrate and isolate flavor. J. Dairy Sci. 88:3826-3839.

Carunchia Whetstine, M. E., J. Parker, M. A. Drake, and D. K. Larick. 2003. Determining flavor and flavor variability in commercially produced liquid Cheddar whey. J. Dairy Sci. 86:439-448.

Caudle, A. D., Y. Yoon, and M. A. Drake. 2005. Influence of flavor variability in skim milk powder on consumer acceptability of ingredient applications. J. Food Sci. 70:S427-S431.

Childs, J. L., M. D. Yates, and M. A. Drake. 2007. Sensory properties of meal replacement bars and beverages made from whey and soy proteins. J. Food Sci. 72:S425-S434.

Croissant, A. E., E. J. Kang, R. E. Campbell, E. Bastian, and M. A. Drake. 2009. Impact of bleaching agent on the flavor and flavor chemistry of whey proteins. J. Dairy Sci. 92:5917-5927.

Drake, M. A. 2006. Flavor and flavor carry-through of whey proteins in beverages. Pages 292-300 in The Wonders of Whey...Catch the Power; Proc. 4th Int. Whey Conf. American Dairy Products Institute, Elmhurst, IL.
Drake, M. A., Y. Karagul-Yuceer, K. R. Cadwallader, G. V. Civille, and P. S. Tong. 2003. Determination of the sensory attributes of dried milk powders and dairy ingredients. J. Sens. Stud. 18:199216.

Drake, M. A., R. E. Miracle, and J. M. Wright. 2009a. Sensory properties of dairy proteins. Chapter 15. Pages 429-448 in Milk Proteins From Expression to Food. Elsevier, New York, NY.

Drake, M. A., J. M. Wright, M. E. Whitson, and M. A. Lloyd. 2009b. Impact of dairy ingredients on the flavour profiles of foods. Chapter 17. Pages 442-466 in Dairy-Derived Ingredients: Food and Nutraceutical Uses. M Corredig, ed. Woodhead Publishing, Great Abington, Cambridge, UK.

Evans, J. P., J. Zulewska, M. Newbold, M. A. Drake, and D. M. Barbano. 2010. Comparison of composition and sensory properties of $80 \%$ whey protein and milk serum protein concentrates. J. Dairy Sci. 93:1824-1843.

Frankel, E. N. 2005. Lipid Oxidation. 2nd ed. The Oily Press, Bridgewater, UK.

Gallardo-Escamilla, F. J., A. L. Kelly, and C. M. Delahunty. 2005. Sensory characteristics and related volatile flavor compound profile of different types of whey. J. Dairy Sci. 88:2689-2699.

International Dairy Foods Association. 2008. Dairy Facts 2008:57-60. International Dairy Foods Association, Washington DC.

Javidipour, I., and M. C. Qian. 2008. Volatile component change in whey protein concentrate during storage investigated by headspace solid-phase microextraction gas chromatography. J. Dairy Sci. Technol. 88:95-104.

Jelen, P. 2000. Whey: Composition, properties, processing, and uses. Pages 2652-2661 in Encyclopedia of Food Science and Technology. 2nd ed. F. J. Francis, ed. Wiley, New York, NY.

Lee, J. H., and D. B. Min. 2009. Changes of headspace volatiles in milk with riboflavin photosensitization. J. Food Sci. 74:C563-C568.

Liaw, I. W., H. Eshpari, P. S. Tong, and M. A. Drake. 2010. The impact of antioxidant addition on flavor of Cheddar and Mozzarella whey and Cheddar whey protein concentrate. J. Food Sci. 75:C559-C569.

Marsili, R. T. 1999. Comparison of solid-phase microextraction and dynamic headspace methods for the GC-MS analysis of light-induced lipid oxidation products in milk. J. Chromatogr. 37:17-23.

Meilgaard, M. M., G. V. Civille, and B. T. Carr. 1999. Sensory Evaluation Techniques. 3rd ed. CRC Press, Boca Raton, FL.

Morr, C. V., and E. Y. W. Ha. 1991. Off-flavors of whey protein concentrates: A literature review. Int. Dairy J. 1:1-11.

Rinn, J. C., C. V. Morr, A. Seo, and J. G. Surak. 1990. Evaluation of nine semipilot scale whey pretreatment modifications for producing whey protein concentrate. J. Food Sci. 55:510-515.

Sattar, A., and J. M. deMan. 1975. Photooxidation of milk and milk products: A review. CRC Crit. Rev. Food Sci. Nutr. 7:13-37.

Smithers, G. W. 2008. Whey and whey proteins-From 'gutter-togold'. Int. Dairy J. 18:695-704.

Tomaino, R. M., L. G. Turner, and D. K. Larick. 2004. The effect of Lactococcus lactis starter cultures on the oxidative stability of liquid whey. J. Dairy Sci. 87:300-307.

van den Dool, H., and P. D. Kratz. 1963. A generalization of the retention index system including linear temperature programmed gas-liquid partition chromatography. J. Chromatogr. 11:463-467.

Wehr, H. M., and J. F. Frank. 2004. Pages 380-382; 427-434; 440-441; 447-449; 480-495 in Standard Methods for the Examination of Dairy Products. American Public Health Association, Washington, DC.

Whitson, M. E., R. E. Miracle, and M. A. Drake. 2010. Sensory characterization of chemical components responsible for cardboard flavor in whey protein. J. Sens. Stud. 25:616-636.

Wright, B. J., S. E. Zevchak, J. M. Wright, and M. A. Drake. 2009. The impact of agglomeration and storage on flavor and flavor stability of whey protein concentrate $80 \%$ and whey protein isolate. J. Food Sci. 74:S17-S29.

Wright, J. M., M. E. Carunchia Whetstine, R. E. Miracle, and M. A. Drake. 2006. Characterization of a cabbage off-flavor in whey protein isolate. J. Food Sci. 71:C91-C96. 